\title{
Reducing Economic Disparity in the Outermost and Border Regions: Assessing Barriers and Opportunities in the Electricity Sector
}

\author{
Dhandy Arisaktiwardhana ${ }^{1, *}$ and Iqbal $\mathrm{Akbar}^{2}$ \\ ${ }^{1}$ Doctoral Program of Innovation Economics, Technische Universität Berlin - Germany \\ ${ }^{2}$ MBA Program of Energy Management, Technische Universität Berlin - Germany
}

\begin{abstract}
Economic disparity is still a major problem threatening Indonesia's future prosperity. Spatial inequality between rural and urban areas remain to exist and is driven by unequal access to and unaffordable cost of the traditional electricity infrastructures. The national electrification ratio reached $91.16 \%$ in 2016. This paper evaluates the feasibility of reforming existing regulations for Indonesia's electricity sector in its light to reduce economic disparities between-regions and intraregions in Indonesia. A systematic review of the literature on the publications and research reports is used to provide inputs for revising the regulations of the electricity sector to address more focused mission-oriented objectives. Empirical models are discussed and established to predict the cost-saving from the reduction of $\mathrm{CO}_{2}$ emission by applying the technological solutions for renewable energy and energy efficiency. This study finds a cost-saving of Rp. 135 trillion per 40.000 hours-use for the whole electricity consumers in Indonesia that can be converted into financial instruments to support the development of electricity infrastructure in the disadvantaged regions. In the end, the study concludes that there is a clear financial benefit, in the form of opportunity cost, for reforming narration of the electricity policy and further transforming the institutional arrangement.
\end{abstract}

Keywords: economic disparity; renewable energy; energy efficiency; $\mathrm{CO}_{2}$ emission reduction

\section{Electricity Access in Economic Equality}

Indonesia has a considerable potency to grow its economy given its growing population and abundant reserves of natural resources. With the predicted population reaching 295 million in 2030, Indonesia will be the fourth largest country in the world [1]. The strong level of economic growth will land the country as the fifth powerful economy in the world in term of GDP leading its neighbours at the Southeast Asia regions. PWC estimates that Indonesian GDP in 2030 will yield 5.424 trillion USD shadowing Japan in the fourth position [2]. However, economic disparity is still a major problem in Indonesia where four Indonesians hold more wealth than the poorest one hundred million [3]. The expanding middle class in the urban areas of Indonesia isn't followed by the income growth of the lower class in the rural areas, i.e. Eastern Indonesia. Pachauri and Spreng revealed that the economic inequality closely mirrored the energy inequality at a global level (see Fig. 1). The poorest $40 \%$ of the world's population only disposes of some $10 \%$ of the global income, hence consumes some $10 \%$ of the final energy use [4]. The lack of infrastructure development for electricity in the outermost and border regions widen the income gap between the rich and the poor in Indonesia.

The ratio of electrification in Indonesia reaches $94.9 \%$ in 2017 summing up to 10.4 million people who live in the dark [5]. Most of the outermost and border regions have poor access to the electricity [6]. The failure to powering the households in the underdeveloped regions may hamper the national target of $97 \%$ electrification ratio in 2019.

\footnotetext{
* corresponding author: dhandy@bsn.go.id
} 
Figure 1: Energy inequality in economic inequality

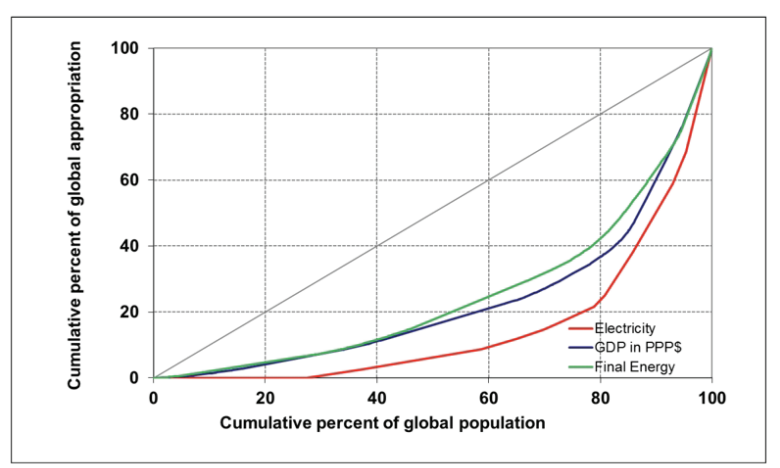

According to the latest data from BPS, the average Gini ratio that is widely used to measure the economic inequality is 0.391 in 2017 - declining 0.003 points from 0.394 in 2016 . This number implies that there is a slight improvement in reducing the gaps in economic disparity in the recent years. However, the number of the bottom $40 \%$ of the Indonesian population in 2017 accounted for the total national spending is slightly higher in the rural areas rather than in urban areas [4]. More people in the rural areas spend less money than the average Indonesians. This income equality is widened in the absence of sufficient electricity access. When there is lack of adequate access to the electricity, public amenities and services can't provide the sufficient support to develop the human dimensions to close the gaps in wealth, employment, and education sectors [4]. In many cases, the lack of electricity can mean high barriers to the accessible water supply and waste treatment making it harder for the GoI to improve the human dimension [7]. The gap in education, employment, and wealth are observed as the main determinants of income inequality [4]. Without substantial supports from GoI to reduce to reduce income equality, the lower economic people in the outermost and border regions can't overcome the poverty.

\section{Research question and methodology}

As argued in the previous section, the lack of electricity infrastructure in the outermost and border regions of Indonesia can widen the economic disparity gaps. This study intends to answer the following research question:

How can the transformation of the electricity sector in the outermost and border regions of Indonesia be used to reduce the economic disparity gaps?

The dynamic governance of the electricity sector is presented to understand the current landscape of the electricity sector in Indonesia. The description of outermost and border regions in Indonesia follows the discussion. The regulations of electricity sector are identified to comprehend the stretch in the legislation between the central government and regional government. The opportunities for adopting the technological solutions on the deployment of off-grid renewable energy generation and household energy efficiency are described hereafter. The empirical analysis to calculate $\mathrm{CO}_{2}$ reduction by applying the proposed solutions. The discussion on the barriers and opportunities to transform the electricity sector are given before withdrawing the final conclusions and recommendations. Empirical modelling will be used to calculate the cost-saving for the households in the disadvantaged regions for using the proposed technology solutions. Systematic literature review (SLR) is used to collect all relevant interdisciplinary researches particularly in the field of policy in the energy sector and innovation in the renewable energy system (RES). Secondary sources are taken from government reports, non-profit organization report, and mass media will be used to support answering the main research question.

\section{Description of Indonesian disadvantages, outermost, and border regions}

With respect to achieve the objectives of sustainable development for the Republic of Indonesia, the development of the region has the objective of realizing the integration in the use of various resources, tracking and balancing the national development and the unity of the national territory, enhancing harmonies between regions, integration between development sectors through spatial planning processes [8]. Geographically, the location of the Republic of Indonesia which lies between two continents and two oceans is very strategic, both for national and international interests. Ecosystemically, Indonesia's natural condition is very distinctive because of its position near the equator with weather, seasons, and tropical climate, which is a great asset or resource for the Indonesian nation [9].

Furthermore, based on Law Number 26 Year 2007 on Spatial Planning, a National Spatial Plan (RTRWN) has been drafted through Government Regulation Number 26 Year 2008 as the direction of policy and strategy of the utilization of state space. One of them is the policy and strategy of national strategic area development, which includes the development of disadvantaged areas to reduce the gap in the level of intergovernmental development. The strategies for the development of underdeveloped areas set forth in Government Regulation Number 26 of 2008 include:

1. utilizing natural resources in an optimal and sustainable manner;

2. open access and increase accessibility between disadvantaged areas and regional growth centres;

3. develop infrastructure and facilities to support community economic activities;

4. increase public access to financing sources; and

5. improve the quality and capacity of human resources in the management of economic activities. 
Disadvantaged areas are the districts whose territories and communities are less developed than other regions on a national scale [10]. An area is designated as a Disadvantaged Area based on the following criteria: the community's economy; human resources; facilities and infrastructure; regional financial capacity; accessibility; and regional characteristics [10]. When the House of Representatives Commission V held a Working Meeting with Minister of Village and Development of Disadvantaged Regions and Transmigration on June 5, 2015 to discuss the performance of Ministry of Village and Disadvantaged Areas and Transmigration (KemenPDT) in 2015 and Government Work Plan 2016, lack of infrastructure and electricity supply is a major problem in disadvantaged areas. As of June 5, 2015, there are still 15,000 villages that have not been powered by electricity [11]. In Indonesia, there are still 122 disadvantaged areas in 24 provinces, as shown in Appendix 1.

The development of the state border area is also the basis for the preparation of the RTRWN [12]. State border areas are districts/municipalities that are geographically and demographically adjacent to neighbouring countries and/or open seas. State border areas include land border areas and marine border areas including the outermost small islands [12]. Indonesia has an international land border with 3 (three) neighbouring countries namely Malaysia, Papua New Guinea, and Timor Leste. Land borders are spread over three islands, namely Kalimantan Island, Papua Island, and Timor Island, where on the islands are located in 5 (five) provinces namely West Kalimantan Province, East Kalimantan, North Kalimantan, Papua and East Nusa Tenggara. While in the territorial waters, Indonesia borders on sovereignty and/or sovereign rights with 10 neighbouring countries namely Malaysia, Papua New Guinea, Timor Leste, India, Thailand, Vietnam, Singapore, Philippines, Palau, and Australia [13]. Based on the identification of land border areas [13] and Appendix 1 - Identification of Underdeveloped Regions, it can be seen that the border areas of the countries in West Kalimantan, East Kalimantan, North Kalimantan, Papua and East Nusa Tenggara are provinces which also have 54 regions / lagging districts.

\section{The Dynamics Governance of Electricity Sector}

The electricity sector is not fully liberalised, and there is not enough counterbalance from the government to ensure that the governance is designed to provide the full benefit for the society. It doesn't only apply for electricity but also for coal and oil \& gas [14]. Directorate General (DG) Electricity and RE act as the policymakers, the licensers, and the regulators in the electricity sector and additional focused sub-sectoral for RE power generation. Such multi-level governances and the overlapping between DG Electricity and RE brings specific conflict of interest for Ministry of Energy and
Mineral Resources (MEMR) because of the interdependency in the decision makings when developing the electricity sector. As the extension of the government hand in the electricity sector, PLN is perceived of having broad remit and power with a number of conflicts of interest in the electricity market the powerful single player, single buyer, and the largest owner of power generation assets in Indonesia [15].

Figure 2 : Electricity regulatory framework in Indonesia

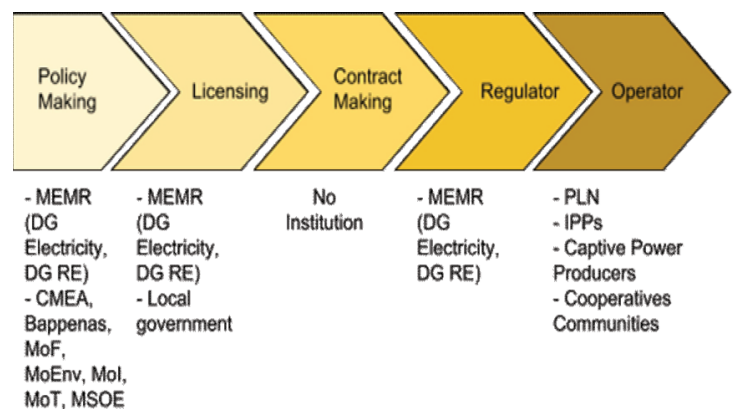

When the policy is designed to create a designated market, the business with the closer power proximity to the policymakers can be granted a mechanism to conduct the business disregards its capacity to maintain a healthy financial performance. Thus, this abuse of power hampers the fair competition bringing more disadvantages to the electricity market. ADB identified that the risk of misalignment between MEMR and local governments in giving the licenses for Independent Power Producers (IPPs), captive power producers, and cooperative communities compromised the attractiveness of the business climate. Different interests inside MEMR and local governments may take a longer time to process the licenses for the private sectors to be completed [14]. BPK found that there are 142 electricity projects for renewable energy unsettled with the total value of $\mathrm{Rp}$. 1,17 trillion. It was suspected, among other reasons, that the asset handovers from the central to the region took significant long time (around six to seven months) because the local government hadn't prepared financial support to operate the assets after being handed over [16].

\section{Indonesian Energy Regulations Identification}

Initiated by President Joko Widodo - Vice President Jusuf Kalla, Nawa Cita is a 9 (nine) program to show the priority of the path of change towards a politically sovereign Indonesia, as well as independent in the field of economy and personality in culture. The provision of Energy Saving Solar Lamp (LTSHE) is one of the implementation of Nawa Cita's program of the President of the Republic of Indonesia in the energy sector to meet the needs of the community that has not been connected with power lines in the foremost, outermost and underdeveloped areas (3T). The provision of LTSHE is regulated in Presidential Regulation No. 47 of 2017 on 
Provision of LTSHE for Communities that Have Not Gained Access to Electricity. The LTSHE program is also supported by MEMR No. 33 of 2017 on Procedures for the Provision of LTSHE for Communities that Have Not Gained Access to Electricity. Solar power is one source of renewable energies. The supply of electricity originating from renewable energy sources to undeveloped areas, remote areas and border areas have been regulated by legislation as shown in Appendix 2 .

\section{Structural Reformation}

Based on the information in Appendix 2 - the identification of Power Supply Regulation Laws for Disadvantaged Regions in Indonesia, the authors identified the following opportunities:

1. The use of renewable energy as the main energy source in electricity supply enterprises in the rural areas lacking basic electricity infrastructure, the remote villages, the rural borders, and the small populated islands. This is in accordance with Law Number 30 Year 2007, Law Number 30 Year 2009, KEN, RUEN and RUKN;

2. Business Entity may become the operator of Small-scale Integrated Power Supply Enterprises. This business entity is a regionalowned enterprise, private business entity, or cooperative incorporated as Indonesian legal entity and established to strive in the field of electricity supply. This electricity supply business includes the generation, transmission, distribution and / or sale of electric power. This is in accordance with Law Number 30 Year 2009.

In accordance with the policy on regional autonomy, it has been arranged to divide the authority of the issuance of electricity business license between Central Government and Regional Government in this case the Minister and the Governor (See Figure 2). The division of authority for the issuance of Electricity Supply Business License for Public Interest as regulated in Law Number 23 Year 2014, as follows [17]:

1. Governor for business entity whose business area is cross districts / municipalities;

2. Minister, for business entity whose business area is cross province; shall be conducted by a State-owned Enterprise and sells electricity and/or leases power grids to holders of power supply licenses granted by the Minister.

Considering that electricity supply enterprises in the rural areas lacking basic electricity infrastructure, the remote villages, the rural borders, and the small populated islands involving the authority of Central Government and Local Government, it is necessary to supervise the implementation of the BOOT scheme.
However, to date, the Central Government has not established a Government Regulation concerning the provision of supervision of electricity supply enterprises in the rural areas lacking basic electricity infrastructure, the remote villages, the rural borders, and the small populated islands. This is not in accordance with Law Number 30 Year 2009 - Article 46.

Whereas, the provision of electric power is the provision of needs for the public interest and also concerning the interests of the state and concerning the competitive market, the Central Government should establish an agency that oversees an independent power market in rural areas that do not yet have basic electricity, rural, border, and small populated islands. The authors view that the establishment of this agency as independent authority for electricity market is required to:

1. prevent unfair business competition;

2. regulate the selling price of electricity;

3. oversee the selling price of electricity;

4. ensure that the provisions of the laws and regulations of the permit are complied with by the holders of the Power Supply Business License;

5. handle consumer complaints;

6. facilitate dispute settlement;

7. protect the environment from greenhouse gas emissions;

8. guarantees power supply.

RUEN and RUPTL have set out the direction of power plant development with EBT sources. The planning of electricity infrastructures is specified in the annually published RUPTL with the approval from MEMR. However, it lacks the coordination with National Energy Committee (DEN) which is assigned to formulate the National Energy Planning (RUEN). The current electricity infrastructure development as planned by PLN seems not supporting the national planning in RUEN to incorporate $23 \%$ of RES in the national energy mix by 2025. This shows that Thus it requires a large-scale power generation development the project is a large project as well as an acceleration of development to pursue RES target until by 2025. There might be potentials for corruption. For example, in the case of budgeting funds for the construction of power plants, especially at the local level, in the process of direct appointment of IPP or contractor. Any rural energy infrastructure development programs without basic electricity infrastructure, remote villages, rural borders, and small island populations listed on KEN, RUEN and RUKN show that the Government is focusing on the energy infrastructure development in the area. This condition makes the energy electricity infrastructure development program considered vulnerable to corruption [18]. The disproportionate amount of power inequality resulted from the corruption may hamper an equal distribution of wealth, thus widening the economic disparity due to the electricity sector. Regardless of whether the corruption is real or perceived, the resulting 
public loss of trust can significantly hamper from the ability of the governments to provide public amenities and services in the electricity sector [3]. Some examples of corrupt practices related to the development of the electricity energy infrastructure that is of particular concern to the Corruption Eradication Commission (KPK) are:

1. Allegations of mega corruption of diesel power plant (PLTD) projects that potentially cost the state Rp. 130 trillion due to the crime markup of the lease project of 5 turbine ships from Turkey [19];

2. New and Renewable Energy Infrastructure Development Project of Fiscal Year 2016, in Deiyai District, Papua Province [20];

3. Allegations of corruption of development projects 34 power plants PT. PLN (Persero) which is not continued [21].

\section{Technological Solutions}

\subsection{Supply Side Consideration: Selection of Renewable Energy System}

Many reports have revealed the underutilised potential of solar irradiation across the archipelago may dampen the diversify of the domestic electricity supply [22, 23, 24]. IRENA identified the potential for $47 \mathrm{GW}$ installed solar capacity in Indonesia by 2030 to electrify the households in the disadvantaged regions [24]. Surprisingly, the current installed capacity is only 27.23 MW [24]. The average national generation cost (BPP) in 2017 is 7.66 USD ct/kWh - increased 0.27 point from 2016 [25]. With the capping of $85 \%$, the price is still too low for allowing the power producers to recover their investments and generate reasonable profits [26]. This situation is less attractive for the expansion of the PV generation where the LCOE in Indonesia is around 40 USD ct/kWh. The cost can only be cut to 20 USD $\mathrm{ct} / \mathrm{kWh}$ in 2030 under the scenario of reducing the $\mathrm{CO}_{2}$ emission up to $100 \mathrm{Gt}$ by 2050 [27]. Despite of the low purchase price offered by PLN, PV generations are still appropriate for the wide-used of off-grid and isolated power installations for rural electrification in the outermost and border regions [28].

From various RES, there are two prospective systems that can support the small-scale off-grid power generation in the disadvantaged regions: (a) solar PV system with batteries system and (b) hybrid solar $\mathrm{PV} /$ diesel system with batteries system. The details of the system configuration can be seen in Figure 3 below. The falling global price of PV modules can lower the capital cost for both system configuration. As of 2015 , IRENA reported that the price of PV modules ranged from 0.52 to $0.72 \mathrm{US} \$ \mathrm{ct} / \mathrm{W}$ [29]. The battery system cost around 11 US\$/W depending on the materials. Diesel generator cost around 5 US\$/W depending on the capacity size [30]. Most of the components have the span of a lifetime up to ten years. The maintenance and replacement works shall apply to PV modules, batteries, and diesel generators to ensure the availability of the system to generate power. Additional costs for PV system are for purchasing the land and civil works for the support of the modules. It estimated that $1 \mathrm{MW}$ of PV production requires 1.3 to 2 ha of land.

Figure 3: System Design for PV System and Hybrid PV/Diesel System

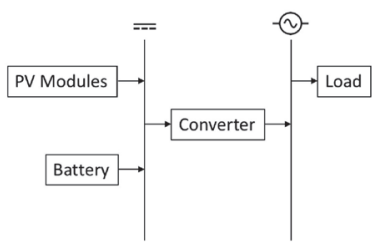

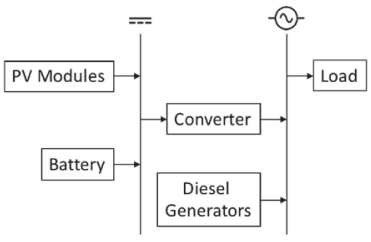

Due to the lower purchasing power in the outermost and border regions, it shall be obligatory for GoI to finance the project and deliver the ownership to the local community (i.e. via Koperasi Unit Desa or BUMDes) as the business sector may not be interested to invest and earn revenue to recover the up-front costs. Empowering the local community with technical skills and expertise to operate and maintain the system is the main key to have a more sustainable energy infrastructure [31, 32, 33]. This nevertheless has not been a focus of the governments in the electricity business as what is stipulated in Law Number 30 Year 2009. The discussion in the electricity infrastructure is limited only to BOOT scheme as such there is no yet instrument to eliminate this barrier. Diesel generators installation can reduce the investment cost during the transition time to the full deployment of solar PV system with batteries system. This is a legit reason due to the higher price of the battery system as compared to the diesel generator. A study shows that the cost of electricity for the solar $\mathrm{PV} /$ diesel hybrid system with battery is cheaper than the stand-alone PV system with batteries system [34]. The lower up-front cost for the diesel gensets contributes to the lower Cost of Energy ( $\mathrm{CoE}$ ) of the hybrid solar $\mathrm{PV} /$ diesel system. The excess power harvested during the daylight by the hybrid solar $\mathrm{PV} /$ diesel system is stored in the battery and used during the night time. When demand exceeds a certain predefined limit, the diesel genset kicks-in and provided additional power for the load demand. The operational cost for fueling the diesel genset may affect the results from the life-cycle economic calculation especially when GoI dismantles the subsidy leaving the true cost of diesel fuel. The calculation for the COE of the solar PV system and hybrid PV/Diesel system are already discussed in various studies $[34,35,36]$. From Figure 2, there is not yet any regulation that manages the purchase of electric power from hybrid systems. The presence of regulatory framework is important, in the view of the authors, for the deployment of RES system in the areas where the economic value is still not attractive for the private sectors. 


\subsection{Demand Side Consideration: Consumers' Energy Efficiency}

Energy conservation is systematic, planned and integrated effort to conserve domestic energy resources and improve the efficiency of its utilization. The implementation of energy conservation encompasses all aspects of energy management i.e. energy supply, energy exploitation, energy utilization and energy resource conservation [37]. Efficiency is one step in the implementation of energy conservation. Energy efficiency is the ratio or other quantitative relationship between an output of performance, service, goods or energy, and input of energy [38]. The application of energy efficient technology is carried out through the establishment and enforcement of energy performance standards on energy utilization equipment. Energy utilization equipment in question is mainly using electrical energy such as refrigerators, lights, irons, air conditioners, rice cookers, electric motors, and others. The application of energy performance standards on energy utilization equipment is carried out by the labeling of energy efficiency levels [39].

To apply clean and efficient technology to the electric power equipment used in the household, the Government shall stipulate Regulation of MEMR Number 18 of 2014 on the Enlargement of Energy Saving Label Signs for Swabalast Lamps. The Government has also enacted the Regulation of the MEMR Number 7 of 2015 on the Application of Minimum Energy Performance Standards (SKEM) and the Inclusion of Energy Efficient Label Labels for the Air Conditioning Appliance. For areas that have been supplied with electricity, the Government should monitor the implementation of energy conservation to meet the provisions of applicable laws and regulations. The government has set a "cut 10 percent" program on May 15, 2016 that aims to make 10 percent energy savings through turning off unused lights and electronic equipment and unplugging the switch. The second way, keep the volume of the cooling machine $(\mathrm{AC})$ at 25 degrees. And the third way is to make energy efficient as the everyday lifestyle of Indonesian people. If this program is done, then we have tried to build a capacity of 3.5-Gigawatt (GW) power plant that requires funds of 43 Trillion Rupiah [40]. There is a great value of energy savings that can be used for power generation in rural areas that lack basic electricity infrastructure, remote villages, rural borders, and small populated islands. Until now, the Government, however, has not yet had regulations on the implementation of SKEM and energy-saving mark label for refrigerators, irons, rice cookers, electric motors, and others. Furthermore, the Government should consider establishing SKEM refrigerator products based on SNI ISO 15502: 2009 [41].

\section{Opportunity Cost for the Selected Technologies}

To know the application of clean and efficient technology to the electricity utilization equipment used in the household, simulation of cost-saving calculation of electric energy usage and $\mathrm{CO}_{2}$ emission reduction in household customer side. This simulation compares 3 (three) electric power utilities namely Incandescent Lamp, Compact Fluorescent Lamp (CFL) and LightEmitting Diode (LED) Lamp. The data used in this simulation are:

1. $\mathrm{CO}_{2}$ Emission Factor from Natural Gas, Coal, Oil, Water and Geothermal [42] [43];

2. Primary Energy used by PT. PLN (Persero) in 2014 from Natural Gas, Coal, Oil, Water and Geothermal [44];

3. Lifetime of Incandescent Lamp, CFL and LED Lamp;

4. Price of Incandescent Lamp, CFL and LED Lamp;

5. Lamp has 900 lumen (assumption);

6. 40.000 hours of lamp usage (assumption);

7. The lamps are used at home with power 1300 VA (assumption);

8. Lamp replacement for 40.000 hours (assumption).

Based on the above data, the calculation of Emission Conversion ( $\mathrm{gr} \mathrm{CO}_{2} / \mathrm{kWh}$ ) as listed in Appendix 3. With the total use of PLN's primary energy in 2014 (derived from coal, natural gas, oil, water and geothermal) of $175.270 .770 .000 \mathrm{kWh}$ and total primary energy emissions of PLN in 2014 (derived from coal, natural gas, water and geothermal) of 125.739.231.473.000 gr of $\mathrm{CO}_{2}$, it can be seen that every $1 \mathrm{kWh}$ of electrical energy generated from PLN power generation for household customers, causing emission of 717,40 gr $\mathrm{CO}_{2}$.

Furthermore, emission conversion calculation results are used to calculate $\mathrm{CO}_{2}$ emission reductions in lamp usage on the household customer side, as shown in Appendix 4. It can be seen that LED lamps can lead to cost-savings in electricity use up to Rp. 2.585.840 and at the same time reduce the $\mathrm{CO}_{2}$ emissions.

\section{Conclusions and Recommendations}

This study shows the barriers to the electricity infrastructure in the outermost and border regions of Indonesia that may widen the economic disparity gaps even further. The structural reformation such as the assignment of the business entity for the operator of small-scale integrated power supply enterprises, the division authority for electricity business licensing, the establishment of independent authority for electricity market, implementation of corruption prevention management (such as the implementation of SNI ISO 37001:2016 [45]), and the formulation of hybrid policy for supporting energy transition are among the suggested opportunities in a manner of a more mission-oriented direction to reduce the disparity gaps. The authors view the adoption of technological solutions on the 
deployment of off-grid PV and hybrid PV/diesel system as the opportunity to close the lack of access to the electricity. In combined with this technological adoption, the use of energy efficient equipment such as the LED lamps can lead to the cost-savings even further and be translated as the opportunity cost to finance the policy instruments for closing the economic disparity gaps. This study finds a cost-saving of Rp. 2.585 .840 per 40.000 hours-use of LED lamp in compared to the incandescent lamp; or is equivalent to Rp. 135 trillion per 40.000 hours-use for the whole electricity consumers in Indonesia. The use of LEDs can reduce $\mathrm{CO}_{2}$ emissions by 1.377 .408 gr $\mathrm{CO}_{2}$ per 40.000 hours-use compared to the incandescent lamp or equal to 71 million tons $\mathrm{CO}_{2}$ per 40.000 hours-use for the whole electricity consumers in Indonesia.

There are some limitations when drawing the conclusions. The authors do not have primary energy data used by PLN in 2014 especially for PV energy source. The potential of PV system and hybrid $\mathrm{PV} /$ hybrid system was not included in the empirical model as such that the "true" cost-saving by implementing these selected technologies was not revealed. The cost-saving by including the solar PV system and hybrid solar PV/diesel system into the energy system is predicted to be larger than the calculation presented in this study. It is however considered as something to be looked at in the future research studies. Secondly, the authors recognise that there might be some issues when translating the regulations into English due to the lack of proper understanding in the legal translation. This might lead to the lexical gaps.

\section{References}

1. http://www.euromonitor.com/indonesia-in-2030the-future-demographic/report

2. https://www.businessinsider.de/ranked-pwcpredicts-the-most-powerful-economies-in-20302017-2?op=1

3. de Haan, J. (2017). Consequences of Inequality in Indonesia: Extremism, Corruption, Economic Cost. Indian Ocean Research Program.

4. Pachuari, S. and Rao, N. (2014). Energy Inequality. Policy Note for IIASA-Alpbach Group.

5. https://theaseanpost.com/article/bringing-electricityrural-indonesia

6. https://www.cnnindonesia.com/ekonomi/201801101 54533-85-267926/rasio-elektrifikasi-2017-diklaimlampaui-target-949-persen

7. http://voxntt.com/2017/10/03/layanan-air-tidakoptimal-warga-pulau-ende-sebut-pdam-tidak-adasolusi/.

8. Trinanda, R.A. and Santoso, E.B. (2013). Penentuan Faktor-Faktor yang Mempengaruhi Ketertinggalan Kawasan Kabupaten Pamekasan. JURNAL TEKNIK POMITS 2(2).

9. Law Number 26 Year 2007 on Spatial Planning.
10. Presidential Regulation No. 131 of 2015 on the Determination of Disadvantaged Regions 2015 2019.

11. http://wikidpr.org/news/rapbn-tahun-2016kementerian-desa-pembangunan-daerah-tertinggaldan-transmigrasi---rapat-kerja-komisi-5-denganmendes

12. Presidential Regulation No. 131 of 2015 on the Determination of Disadvantaged Regions 2015 2019.

13. Regulation of Border Management National Agency No. 1 of 2015 on the Master Plan of State Border Management 2015 - 2019.

14. https://www.adb.org/sites/default/files/projectdocument/176267/ino-energy-white-paper.pdf

15. http://www.iisd.org/sites/default/files/publications/r oadblocks-indonesia-renewable-energy.pdf

16. https://bisnis.tempo.co/read/1043960/142-proyekebt-mangkrak-diduga-karena-rencana-esdm-takmatang

17. Law Number 23 Year 2014 on Regional Government.

18. http://kabar24.bisnis.com/read/20151022/16/484784 /operasi-penangkapan-kpk-infrastruktur-energirawan-korupsi

19. https://www.lensaindonesia.com/2018/02/13/kpkagendakan-gelar-perkara-dugaan-mega-korupsidirut-pln-mark-proyek-pltd-sewa-5-kapal-turki.html

20. https://nasional.kompas.com/read/2015/11/13/21201 811/Sudirman.Said.Sebut.Proposal.Pembangkit.Listr ik.Deiyai.Ditolak.Berkali-kali

21. https://antikorupsi.org/id/news/mengurai-proyekmangkrak-di-pln

22. http://www.atlanticcouncil.org/images/publications/ Indonesias Diversification Challenge web 0919.p df

23. OECD. (2015). OECD Economics Surveys Indonesia: March 2015 Overview.

24. https://www.irena.org//media/Files/IRENA/Agency/Publication/2017/Mar/ IRENA_REmap_Indonesia_report 2017.pdf

25. https://www.esdm.go.id/assets/media/content/conten t-bpp-pembangkitan-listrik-2017.pdf

26. http://www.iisd.org/sites/default/files/publications/r oadblocks-indonesia-renewable-energy.pdf

27. http://www.jocet.org/vol5/402-ES045.pdf

28. Asian Development Bank. (2016). Indonesia: Energy Sector Assessment, Strategy, and Road Map. Mandaluyong City: Asian Development Bank.

29. IRENA. (2016). The power to change: Solar and Wind Cost Reduction Potential to 2025.

30. Lau et al. (2015). Photovoltaics system for Malaysian islands: Effect of interest rates, diesel prices and load sizes. Energy 83:204-216.

31. Akbar, I. (2017). Understanding the Partnership Landscape for Renewable Energy Development in Indonesia. PRCSD Universitas Paramadina.

32. https://www.pv-tech.org/interviews/pv-talk-beatingupfront-costs-of-off-grid-renewables-in-indonesia

33. Restnanestri, et al. (2005). Offgrid Photovoltaic Applications in Indonesia: An Assessment of 
Current Experience. Renewable Energy for a Sustainable Future (ANZSES).

34. Bukar et la. (2017). Economic Assessment of a PV/Diesel/Battery Hybrid Energy System for a Non-electrified Remote Village in Nigeria. European Journal of Engineering Research and Science, 2(1):21- 31 .

35. Shaahid, S.M. and El-Amin, I. (2009). Technoeconomic evaluation of off-grid hybrid photovoltaic-diesel-battery power systems for rural electrification in Saudi Arabia-A way forward for sustainable development. Renewable and Sustainable Energy Reviews, 13(3):635-633.

36. Madziga, M. et al. 2018. Comparison between Three Off-Grid Hybrid Systems (Solar Photovoltaic, Diesel Generator and Battery Storage System) for Electrification for Gwakwani Village, South Africa. Environments 2018, 5, 57.

37. Government Regulation No. 70 of 2009 on Energy Conservation.

38. ISO 50001:2011 - Energy management systems Requirements with guidance for use.

39. Regulation of the Minister of Energy and Mineral Resources Number 18 of 2014 concerning the Enlargement of Energy Saving Label Labels for Swabalast Lamps.

40. https://medium.com/@alfinfadhilah/kelangsungankonservasi-energi-di-indonesia-696382dfad32

41. SNI ISO 15502: 2009 - Refrigerators for households - Characteristics and test methods.

42. $\mathrm{CO}_{2}$ Emissions from Fuel Combustion Highlights. (2016). IEA Statistics.

43. Yuniarto, Soesilo, T.E.B., and Heviati, E. (2015). Geothermal Power Plant Emissions in Indonesia. Proceedings World Geothermal Congress, Melbourne.

44. PLN Statistics. (2014).

45. SNI ISO 37001:2016 - Anti-Bribery Management Systems.

\section{Appendix 1}

Identification of Disadvantaged Areas in Indonesia

\begin{tabular}{|c|c|c|}
\hline No & Province & $\begin{array}{c}\text { Number of } \\
\text { Districts / } \\
\text { Disadvantaged } \\
\text { Areas }\end{array}$ \\
\hline 1 & Aceh & 1 \\
\hline 2. & Sumatera Utara & 4 \\
\hline 3. & Sumatera Barat & 3 \\
\hline 4. & Sumatera Selatan & 2 \\
\hline 5. & Bengkulu & 1 \\
\hline
\end{tabular}

\begin{tabular}{|c|c|c|}
\hline No & Province & $\begin{array}{c}\text { Number of } \\
\text { Districts / } \\
\text { Disadvantaged } \\
\text { Areas } \\
\end{array}$ \\
\hline 6. & Lampung & 2 \\
\hline 7. & Jawa Timur & 4 \\
\hline 8. & Banten & 2 \\
\hline 9. & Nusa Tenggara Barat & 8 \\
\hline 10. & $\begin{array}{c}\text { Nusa Tenggara } \\
\text { Timur }\end{array}$ & 18 \\
\hline 11. & Kalimantan Barat & 8 \\
\hline 12. & Kalimantan Tengah & 1 \\
\hline 13. & Kalimantan Selatan & 1 \\
\hline 14. & Kalimantan Utara & 1 \\
\hline 15. & Kalimantan Timur & 1 \\
\hline 16. & Sulawesi Tengah & 9 \\
\hline 17. & Sulawesi Selatan & 1 \\
\hline 18. & Sulawesi Tenggara & 3 \\
\hline 19. & Gorontalo & 3 \\
\hline 20. & Sulawesi Barat & 2 \\
\hline 21. & Maluku & 8 \\
\hline 22. & Maluku Utara & 6 \\
\hline 23. & Papua Barat & 7 \\
\hline 24. & Papua & 26 \\
\hline & TOTAL & 122 \\
\hline
\end{tabular}




\section{Appendix 2}

Identification of Power Supply Regulation Legislation for Disadvantaged Regions in Indonesia

\begin{tabular}{|c|c|c|}
\hline No. & Legislation & Contents \\
\hline 1. & $\begin{array}{l}\text { Law Number } 30 \text { Year } \\
2007 \text { on Energy - } \\
\text { Article } 20\end{array}$ & $\begin{array}{l}\text { Energy supply by the Government and / or local } \\
\text { government is prioritized in undeveloped, } \\
\text { remote, and rural areas using local energy } \\
\text { sources, especially renewable energy sources. }\end{array}$ \\
\hline 2. & $\begin{array}{l}\text { Law Number } 30 \text { Year } \\
2009 \text { on Electricity - } \\
\text { Article } 3 \text { Paragraph } 1\end{array}$ & $\begin{array}{l}\text { The provision of electricity is controlled by the } \\
\text { state which is implemented by the Government } \\
\text { and local government based on the principle of } \\
\text { regional autonomy. }\end{array}$ \\
\hline 3. & $\begin{array}{l}\text { Law Number } 30 \text { Year } \\
2009 \text { on Electricity - } \\
\text { Article } 4 \text { Paragraph } 3\end{array}$ & $\begin{array}{l}\text { For the provision of electricity referred to in } \\
\text { Article } 3 \text { paragraph (1), the Government and } \\
\text { local governments provide funds to: } \\
\text { a. community groups cannot afford; } \\
\text { b. construction of power supply facilities } \\
\text { in undeveloped areas; }\end{array}$ \\
\hline & & c. power generation in remote and border \\
\hline
\end{tabular}

\begin{tabular}{|c|c|c|}
\hline No. & Legislation & Contents \\
\hline & & $\begin{array}{l}\text { areas; and } \\
\text { d. construction of rural electricity. }\end{array}$ \\
\hline 4. & $\begin{array}{l}\text { Law Number } 30 \text { Year } \\
2009 \text { on Electricity - } \\
\text { Article } 10\end{array}$ & $\begin{array}{l}\text { 1) The business of providing electricity for the } \\
\text { public interest as referred to in Article } 9 \text { Letter } \\
\text { a, covers the following type of business: } \\
\text { a. power generation; } \\
\text { b. electric power transmission; } \\
\text { c. power distribution; and / or } \\
\text { d. sales of electric power. } \\
\text { 2) The business of providing electricity for the } \\
\text { public interest as referred to in paragraph (1) } \\
\text { may be carried out in an integrated manner. }\end{array}$ \\
\hline
\end{tabular}




\begin{tabular}{|c|c|c|}
\hline No. & Legislation & Contents \\
\hline 5. & $\begin{array}{l}\text { Law Number } 30 \text { Year } \\
2009 \text { on Electricity - } \\
\text { Article } 11\end{array}$ & $\begin{array}{l}\text { 1) Public power supply business as referred to } \\
\text { in Article } 10 \text { paragraph (1) shall be carried out } \\
\text { by state-owned enterprises, regional } \\
\text { government-owned enterprises, private business } \\
\text { entities, cooperatives, and self-supporting } \\
\text { communities in the field of electricity supply. } \\
\text { 2) State-owned enterprises as referred to in } \\
\text { paragraph (1) shall be given the first priority of } \\
\text { doing business of providing electricity for the } \\
\text { public interest. } \\
\text { 3) For regions that have not received power } \\
\text { service, the Government or regional government } \\
\text { in accordance with its authority to provide } \\
\text { opportunities to regional-owned enterprises, } \\
\text { private entities, or cooperatives as the provision } \\
\text { of integrated power supply business. } \\
\text { 4) In the absence of a locally-owned enterprise, } \\
\text { a private enterprise or a cooperative that can } \\
\text { provide electricity in the region, the } \\
\text { Government shall assign a state-owned } \\
\text { enterprise to provide electricity. }\end{array}$ \\
\hline
\end{tabular}

\begin{tabular}{|c|c|c|}
\hline No. & Legislation & Contents \\
\hline 6. & $\begin{array}{l}\text { Government } \\
\text { Regulation Number } 79 \\
\text { Year } 2014 \text { on National } \\
\text { Energy Policy - Article } \\
20 \text { Paragraph } 2 \text { (b) }\end{array}$ & $\begin{array}{l}\text { Calculation of Rational Energy prices for the } \\
\text { supply of Renewable Energy from local sources, } \\
\text { in the context of securing energy supplies in } \\
\text { certain remote areas, undeveloped facilities and } \\
\text { infrastructure, vulnerable to weather } \\
\text { disturbances, or near the border area of the } \\
\text { Unitary State of the Republic of Indonesia. }\end{array}$ \\
\hline 7. & $\begin{array}{l}\text { Government } \\
\text { Regulation Number } 79 \\
\text { Year } 2014 \text { on National } \\
\text { Energy Policy (KEN) - } \\
\text { Article } 22 \text { Paragraph } 2\end{array}$ & $\begin{array}{l}\text { The Government and Local Government } \\
\text { provide incentives for the development, } \\
\text { utilization and utilization of renewable energy, } \\
\text { especially for small scale and located in remote } \\
\text { areas until the economic value is competitive } \\
\text { with conventional energy. }\end{array}$ \\
\hline 8. & $\begin{array}{l}\text { Presidential Regulation } \\
\text { No. 22 of } 2017 \\
\text { concerning the General } \\
\text { Plan of National } \\
\text { Energy (RUEN) - } \\
\text { Annex II }\end{array}$ & $\begin{array}{l}\text { Prioritizing the provision of energy for people } \\
\text { who do not have access to electricity, gas and } \\
\text { household energy and energy for transportation, } \\
\text { industry and agriculture (Program: Energy } \\
\text { Infrastructure Development). } \\
\text { Development of energy by prioritizing local } \\
\text { energy resources (Program: Improved } \\
\text { Utilization of New and Renewable Energy). }\end{array}$ \\
\hline
\end{tabular}




\begin{tabular}{|c|c|c|}
\hline No. & Legislation & Contents \\
\hline 9. & $\begin{array}{l}\text { Minister of Energy and } \\
\text { Mineral Resources } \\
\text { Decree No. } 2682 \mathrm{~K} / \\
21 \text { / MEM / } 2008 \text { on } \\
\text { National Electricity } \\
\text { General Plan } 2008 \text { - } \\
2027 \text { (RUKN) }\end{array}$ & $\begin{array}{l}\text { One of the missions of the electricity sector: } \\
\text { giving priority to power generation from } \\
\text { renewable energy for rural and remote } \\
\text { electricity. }\end{array}$ \\
\hline 10. & $\begin{array}{l}\text { Regulation of Minister } \\
\text { of Energy and Mineral } \\
\text { Resources Regulation } \\
\text { No. } 38 \text { of } 2016\end{array}$ & $\begin{array}{l}\text { Small-scale Electricity Supply Enterprises with } \\
\text { a total capacity of up to } 50 \mathrm{MW} \text { power systems } \\
\text { were established in the rural areas lacking basic } \\
\text { electricity infrastructure, the remote villages, the } \\
\text { rural borders, and the small populated islands. } \\
\text { The Government and / or regional government } \\
\text { shall give the opportunity to the Business Entity } \\
\text { to become the operator of Small-scale Integrated } \\
\text { Power Supply Enterprises. }\end{array}$ \\
\hline 11. & $\begin{array}{l}\text { Regulation of the } \\
\text { Minister of Energy and } \\
\text { Mineral Resources } \\
\text { Number } 10 \text { of } 2017 \\
\text { and Minister of Energy } \\
\text { and Mineral Resources } \\
\text { Regulation No. } 12 \text { of } \\
2017\end{array}$ & $\begin{array}{l}\text { Purchase of electric power from solar power, } \\
\text { wind power, hydropower, biomass power, } \\
\text { biogas power, geothermal and sea water power } \\
\text { use cooperation Build, Own, Operate, and } \\
\text { Transfer (BOOT). }\end{array}$ \\
\hline
\end{tabular}

\begin{tabular}{|c|c|c|}
\hline No. & \multicolumn{1}{|c|}{ Legislation } & \multicolumn{1}{c|}{ Contents } \\
\hline 12. & $\begin{array}{l}\text { Regulation of Minister } \\
\text { of Energy and Mineral } \\
\text { Resources Regulation } \\
\text { No. 50 of 2017 }\end{array}$ & $\begin{array}{l}\text { Purchase of electricity from solar power, wind } \\
\text { power, hydropower, biomass power, biogas } \\
\text { power, geothermal power and sea water power } \\
\text { using cooperative pattern of building, owning, } \\
\text { operating and transferring (BOOT). }\end{array}$ \\
\hline
\end{tabular}

\section{Appendix 3}

The calculation of emission Conversion $\left(\mathrm{gr} \mathrm{CO}_{2} / \mathrm{kWh}\right)$

\begin{tabular}{|c|c|c|c|}
\hline $\begin{array}{l}\text { Primary } \\
\text { Energy at } \\
\text { PLN }\end{array}$ & $\begin{array}{l}\text { Use of Primary } \\
\text { Energy at PLN in } \\
2014(\mathrm{kWh})\end{array}$ & $\begin{array}{l}\text { Emission } \\
\text { Factor (gr } \\
\left.\mathrm{CO}_{2} / \mathbf{k W h}\right)\end{array}$ & $\begin{array}{l}\text { Primary Energy Emission } \\
\text { at PLN }\left(\text { gr } \mathrm{CO}_{2}\right)=[\mathrm{Use} \text { of } \\
\text { Primary Energy at PLN in } \\
2014(\mathrm{kWh})] \times[\text { Emission } \\
\left.\text { Factor }\left(\mathrm{gr} \mathrm{CO}_{2} / \mathrm{kWh}\right)\right]\end{array}$ \\
\hline Natural Gas & 49.312 .480 .000 & 405 & 19.971 .554 .400 .000 \\
\hline Coal & 84.076 .120 .000 & 1030 & 86.598 .403 .600 .000 \\
\hline
\end{tabular}




\begin{tabular}{|l|l|l|l|}
\hline $\begin{array}{l}\text { Primary } \\
\text { Energy at } \\
\text { PLN }\end{array}$ & $\begin{array}{l}\text { Use of Primary } \\
\text { Energy at PLN in } \\
\text { 2014 (kWh) }\end{array}$ & $\begin{array}{l}\text { Emission } \\
\text { Factor (gr } \\
\left.\mathbf{C O}_{2} / \mathbf{k W h}\right)\end{array}$ & $\begin{array}{l}\text { Primary Energy Emission } \\
\text { at PLN (gr CO }) \text { [ [Use of } \\
\text { Primary Energy at PLN in } \\
\text { 2014 (kWh)] X [Emission } \\
\text { Factor }\left(\mathbf{g r} \mathbf{C O}_{2} / \mathbf{k W h}\right)\end{array}$ \\
\hline Oil & 26.433 .180 .000 & 715 & 18.899 .723 .700 .000 \\
\hline Water & 11.163 .620 .000 & 0 & 0 \\
\hline Geothermal & 4.285 .370 .000 & 62,90 & 269.549 .773 .000 \\
\hline & & & 125.739 .231 .473 .000 \\
\hline T O T A L & 175.270 .770 .000 & - & \\
\hline
\end{tabular}

Emissions Conversion $=\left[\right.$ Total Primary Energy Emission at PLN $\left.\left(\mathrm{gr} \mathrm{CO}_{2}\right)\right] /[$ Total Use of Primary Energy at PLN in $2014(\mathrm{kWh})]=717,40 \mathrm{gr} \mathrm{CO}_{2} / \mathrm{kWh}$

\section{Appendix 4}

Cost-Savings of Electrical Energy (Rp.) and $\mathrm{CO}_{2}$ Reduction ( $\mathrm{gr} \mathrm{CO}_{2}$ ) to Household Customers

\begin{tabular}{|l|l|l|l|l|l|}
\hline No. & \multicolumn{1}{|c|}{ Description } & Unit & a & b & c \\
\hline 1 & Life Time & hours & 4.000 & 8.000 & 40.000 \\
\hline 2 & $\begin{array}{l}\text { Power Consumption } \\
\text { for } 900 \text { Lumen }\end{array}$ & $\mathrm{W}$ & 60 & 18 & 12 \\
\hline 3 & $\begin{array}{l}\text { Lamp's Price } \\
4\end{array}$ & $\mathrm{Rp}$. & 7.500 & 29.500 & 85.000 \\
\hline 5 & $\begin{array}{l}\text { Lamp usage for } \\
40.000 \text { hours } \\
\text { CO }{ }_{2} \text { emissions } \\
\text { during } 40.000 \text { hours } \\
\text { of usage (No. } 4 \mathrm{x} \\
717,40 \text { gr } \\
\text { CO } / \mathrm{kWh})\end{array}$ & $\mathrm{kWh}$ & 2.400 & 720 & 480 \\
\hline
\end{tabular}




\begin{tabular}{|c|c|c|c|c|c|}
\hline No. & Description & Unit & $\mathbf{a}$ & b & c \\
\hline 6 & $\begin{array}{l}\text { Electricity Tariff } \\
\text { (power assumption } \\
\text { 1.300 VA @ Rp. } \\
\text { 1.352/kWh) (No. } 4 \\
\text { x Rp. 1.352/kWh) }\end{array}$ & Rp. & 3.244 .800 & 973.440 & 648.960 \\
\hline 7 & $\begin{array}{l}\text { Lamp Replacement } \\
\text { For } 40.000 \text { hours }\end{array}$ & times & 10 & 5 & 1 \\
\hline 8 & $\begin{array}{l}\text { Lamp Replacement } \\
\text { Costs for } 40.000 \\
\text { hours (No. } 6 \text { x No. } \\
\text { 3) }\end{array}$ & Rp. & 75.000 & 147.500 & 85.000 \\
\hline 9 & $\begin{array}{l}\text { Total Cost for } \\
40.000 \text { hours (No. } 5 \\
+ \text { No. } 7 \text { ) }\end{array}$ & Rp. & 3.319 .800 & 1.120 .940 & 733.960 \\
\hline
\end{tabular}

$\mathrm{a}=$ Incandescent Lamp

$\mathrm{b}=$ Compact Fluorescent Lamp (CFL)

$\mathrm{c}=$ Light-Emitting Diode (LED) Lamp 